\title{
Efficient methods of selection and growing seeds of vegetable and vine crops
}

\author{
V. Kravchenko, \\ Academician of the NAAS, Doctor of Agricultural Sciences, \\ National Academy of Agrarian Sciences of Ukraine \\ S. Korniyenko, \\ Doctor of Agricultural Sciences, \\ S. Kondratenko, \\ Candidate of Biological Sciences, \\ O. Serghiyenko, \\ Candidate of Agricultural Sciences, \\ T. Gorova, \\ Academician of the NAAS, Doctor of Agricultural Sciences, \\ O. Samovol, \\ Doctor of Agricultural Sciences, \\ O. Saiko \\ Candidate of Agricultural Sciences \\ Institute of Vegetable and Melons growing of NAAS
}

The purpose. To discuss methods of selection and growing seeds of vegetable and vine crops. Methods. Analytical, calculative-analytical, statistical, field and laboratory assessments. Results. On the basis of long-term researches methods selection and growing seeds of vegetable and vine crops protected by patents are developed. Application of new methods has enabled to optimize selection process that promoted deriving transgressive forms with new combination of economically valuable attributes controllable by recessive genes; to enlarge genetic diversity of populations due to emersion of new recombinant and transgressive forms at remote hybridization; to improve attributes of cold hardiness and keeping quality; to reduce the content of nitrates; to increase for $50 \%$ productivity of seeds and for $20-30 \%$ their quality; to improve quality of raw material for tinned goods; to prolong times of their consumption; to reduce expenditures for selection and to increase profit at growing commodity vegetables and seeds. Conclusions. Methods of selection and growing seeds of vegetable and vine crops allowing speed up in 2,5 - 3 times selection and seed-growing processes are developed. They also promote creation of initial stock, grades and hybrids with the heightened solid basis, general sugar, ascorbic acid, beta-carotene, to create plants resistant against action of stressful bio- and abiotic factors. New grades and hybrids are included into the Catalogue of grades of plants recommended for use inUkraine.

Key words: methods, selection, genetics, seeds growing, lines, biogeotechnology, induced mutagenesis, ecological heterosis.

Institute of Vegetables and Melons growing of NAAS is playing a leading role as the originator to create the new competitive varieties and hybrids $\mathrm{F} 1$ of vegetable and melon crops. In order to ensure the high competitiveness of breeding research, the Institute has already increased the level of theoretical and marketing research in the direction of developing modern models of varieties and hybrids of vegetable and melon crops, which meet the requirements of industrial and small-scale production. The creation of new breeding genotypes requires the availability of source material with a complex of valuable economic characteristics: productivity and quality of plant products, resistance to abiotic and biotic factors. A variety or hybrid F1 of plants as a basis for production technology can realize its productive potential and technological qualities only in specific ecological and geographical conditions [1-3]. In recent years, there has already been a sig- 
nificant increase in average daily air temperatures of $0.2-2.7 \stackrel{\circ}{\circ}$, with a decrease in precipitation (by 42 $\mathrm{mm}$ ). This has already forced adjusting breeding programs for the further development of highly adaptive varieties and hybrids of vegetable and melon crops and new technologies of their cultivation, especially organic farming. Vegetable and melons of plants help to cleanse the human body from harmful substances and provide fresh processed products for a year. That is why the theoretical and methodological direction of research should be to improve the methodology of selection and seeding process and update the gene pool of vegetable and melon species of plants with new valuable genetic sources.

Material and methods of research. Breeding studies have already been carry out at the experimental bases of the Institute of Vegetable and Melons growing of NAAS.

Objects of research: tomato, sweet pepper, bitter pepper, eggplant, cucumber, table beet, carrots, cabbage, vegetable bean, leafy salad, parsley curly, celery root, sugar corn, watermelon, potatoes.

In the course of breeding and sowing of research, all selective-valuable samples of wild and semicultivated forms of tomatoes were used - 12, tomatoes - 217 for open soil and 131 for protected soil; sweet pepper - 628 , bitter pepper - 28 , eggplant - 264 , beet table -150 , cabbage of the whitish - 62 , parsley curly - 96 , celeriac of root crop - 26 , leaf lettuce -173 , watermelon -23 , potatoes -6 .

Field, breeding and seed researches were carry out according to the standard methods described in the monographs: "Modern methods of selection of vegetable and melon plants" (2001) [4], "Methodology of experimental work in vegetable and melon" (2001) [5], "Seed production and semenology of vegetable and melon cultures "(2003) [6]. The generally accepted agrotechnical techniques and methods described in the paper [7], in the monographs "Scientific and practical approaches of breeding and seeding of beet dining, were used. Theory and Practice "[8]," Alternative Methods in the Selection of Vegetable and Melon Plant Species "[9] and in the original works of foreign scientists [10-14].

Biochemical evaluation of consumer organs of vegetable species was carry out measurements of IVM of NAAS [15].

Results of researchers. Analysis of the results of selection of vegetable and melon cultures showed that over the past two decades, scientists of the Institute of Vegetable and Melons growing of NAAS have developed and implemented a selection of methods in the selection practice. They contributed to the expansion of the genetic variability of the gene pool of vegetable plants for the use of semicultural, wild and mutant forms [9].

In particular, it has been shown that the expansion of genotype variability can be achieved by growing hybrids F1 of pasture plants in stressful conditions of lack of nutrition, thickening, water availability, with the separation of seeds from different breeds (PCM*№46947 UA).

The expansion of the genotype variability ware achieved by selecting on the background of the poorly adapted F1 hybrids for the purity of the meiosis of the various layers of placement of the bridles. The buds were characterize by the highest incidence of interstitial chiasm and atypical bivalents for processing them with a $0.04 \%$ solution of nicotinamide (PCM №80143 UA).

Note: PCM is a patent for a utility model.

The creation of new tomato output genotypes helped to select them from the background of hybrid populations from 4-6 distant crossings. In addition, the selection among populations F1 for the manifestation of low interstitial chiasm for meiocyte and high content of biologically valuable components based on the absence of meiotic bivalents with three chiasms on meiocytes (PCM №38759 UA).

In the selection of highly heterozygous F1 watermelon hybrids, their identification was recommend in the competitive conditions of Wagner vessels for the maximum manifestation of the desired signs and the minimum frequency of chiasm on meiocyte (PCM №38793 UA).

Stabilization of the initial material by creating diploid homozygous forms (apomicts) was obtain:

- in cabbage by treating castrated buds with an aqueous mixture of growth regulators, with the addition of pollen of Chinese radish Lobo (Convar lobo Sazon) (PCM № 82889 UA); 
- sweet pepper - the treatment of castrated buds with a mixture of water regulators of growth and application on the pollen of petunia garden pollen (Petunia axillaris Petunia integrifolia, group Petunia multiflora) (PCM № 82889 UA).

Already a method for the formation of potato androgenetic origin in the culture of isolated cucumber in vitro has been developed for the use of biologically active compounds, regulators of phytohormonal action (PV * №98411 UA).

The evaluation and selection of tomato raw material for resistance to alternaria was carried out by immersing the root system of plant varieties and hybrid populations of 20 days of age for 48 hours in a culture fungus filtrate Alternaria solani Sorauer) (PCM №27861 UA).

The breeders of the IOB NAAN have already developed schemes of breeding and seed production of a number of vegetable species based on the use of environmental heterosis and induced mutagenesis. In this way, new lines and varieties of common beans ware create. The source material ware grown in different soil-climatic zones of Ukraine, distinguishes the best samples from the set of desirable signs, and reproduces in the same zone for three years, continuing the evaluation and selection (Table 1). This method reduces the selection of seed and seed production process three times, creating the lines and varieties, helps to stabilize the features, increases productivity (PCM №100994 UA).

${ }^{*}$ Note: PV - patent for invention.

\section{Comparative characteristic of new and traditional ways of creating lines and varieties of beans} of the usual bush type

\begin{tabular}{|c|c|c|c|c|c|}
\hline \multirow[t]{2}{*}{ Year } & \multicolumn{2}{|l|}{ Traditional scheme } & \multirow[t]{2}{*}{ Year } & \multicolumn{2}{|c|}{ New scheme } \\
\hline & nursery & stage of work & & nursery & stage of work \\
\hline $1-3$ & Collectible & $\begin{array}{l}\text { studying the gene } \\
\text { pool and identifying } \\
\text { sources }\end{array}$ & 1 & Collectible & $\begin{array}{l}\text { Estimation by a set of } \\
\text { useful features in the } \\
\text { zones of steppe, forest- } \\
\text { steppe, Polissya and the } \\
\text { selection of mass selec- } \\
\text { tion of samples with zon- } \\
\text { al distinctive features } \\
\text { and adaptability and dis- } \\
\text { tinctive features }\end{array}$ \\
\hline 4 & $\begin{array}{l}\text { Individual selec- } \\
\text { tions }\end{array}$ & $\begin{array}{l}\text { selection from plant } \\
\text { sources by pheno- } \\
\text { type and a set of } \\
\text { features }\end{array}$ & 2 & Selection & $\begin{array}{l}\text { Reproduction of } P \text { in the } \\
\text { growing zone, evaluation } \\
\text { of the original sample } \\
\text { with the standard and the } \\
\text { original form }\end{array}$ \\
\hline 5 & $\begin{array}{l}\text { Selection I genera- } \\
\text { tion }\end{array}$ & $\begin{array}{l}\text { the study of individ- } \\
\text { ual choices and the } \\
\text { selection of the best } \\
\text { phenotypes }\end{array}$ & 3 & Selection & $\begin{array}{l}\text { Reproduction of } \mathrm{P}_{2} \text { in the } \\
\text { growing zone, evaluation } \\
\text { of the original sample } \\
\text { with the standard and the } \\
\text { original form }\end{array}$ \\
\hline 6 & $\begin{array}{l}\text { Selection II genera- } \\
\text { tion }\end{array}$ & $\begin{array}{l}\text { the study of individ- } \\
\text { ual choices and the } \\
\text { selection of the best } \\
\text { phenotypes }\end{array}$ & 4 & Selection & $\begin{array}{l}\text { Reproduction of } \mathrm{P}_{\text {in }} \text { in the } \\
\text { growing zone, evaluation } \\
\text { of the original sample } \\
\text { with the standard and the } \\
\text { original form, transfer to } \\
\text { NTSGRPU (for lines) }\end{array}$ \\
\hline
\end{tabular}




\begin{tabular}{|c|c|c|c|c|c|}
\hline 7 & $\begin{array}{l}\text { Selection III gen- } \\
\text { eration }\end{array}$ & $\begin{array}{l}\text { family study and se- } \\
\text { lection }\end{array}$ & $4-6$ & Reproduction & $\begin{array}{l}\text { Reproduction of feed and } \\
\text { basic seed, transfer to } \\
\text { the DSOPS variety }\end{array}$ \\
\hline $8-9$ & Control & $\begin{array}{l}\text { Assessment on the } \\
\text { DHS test }\end{array}$ & & & \\
\hline $10-11$ & $\begin{array}{l}\text { Preliminary sort } \\
\text { testing }\end{array}$ & $\begin{array}{l}\text { assessment for the } \\
\text { DHS and comparison } \\
\text { with the standard }\end{array}$ & & & \\
\hline $12-14$ & $\begin{array}{l}\text { Competitive variety } \\
\text { testing }\end{array}$ & $\begin{array}{l}\text { assessment of } \\
\text { adaptability and } \\
\text { competitiveness }\end{array}$ & & & \\
\hline $15-16$ & Reproduction & $\begin{array}{l}\text { receipt of the seeds, } \\
\text { transfer to the } \\
\text { DSOPS }\end{array}$ & & & \\
\hline 17 & Reproduction & obtaining basic seed & & & \\
\hline \multicolumn{3}{|c|}{ Only 17 years } & \multicolumn{3}{|c|}{ Only 6 years } \\
\hline
\end{tabular}

Because of this method, methods of breeding new varieties of beans of the usual bush type have already been develop. They grow it in different soil-climatic zones of Ukraine and multiply in other zones. Seeds of the best samples from three zones are unite and cultivated in the most favorable zone for the formation of signs of productivity and quality (Table 2 ).

The method increases the yield by $40 \%$ and the quality of the seeds - up to $28 \%$, reduces the period of cultivating sunflower seeds for 2 years.

2. Comparative characteristics of the new method and the traditional scheme of propagation of beans seeds of the usual vegetable variety Gayidarska

\begin{tabular}{|c|c|c|c|c|c|c|c|}
\hline \multirow[t]{2}{*}{ Years } & \multirow[t]{2}{*}{ Nursery and operations } & \multicolumn{2}{|l|}{ Zones } & \multicolumn{2}{|c|}{ Seeds yield, t/ha } & \multicolumn{2}{|c|}{ Protein content, \% } \\
\hline & & Traditional & New & $\begin{array}{l}\text { Tradi- } \\
\text { tional }\end{array}$ & New & $\begin{array}{l}\text { Tradi- } \\
\text { tional }\end{array}$ & New \\
\hline I & $\begin{array}{l}\text { RVR - 1 Selection of seed } \\
\text { plants of individual fami- } \\
\text { lies at the output of the } \\
\text { seed and architectonics } \\
\text { of the bush on the basic } \\
\text { crop and picking for the } \\
\text { average }\end{array}$ & $\begin{array}{l}\text { Forest- } \\
\text { step left } \\
\text { bank }\end{array}$ & $\begin{array}{l}\text { Forest- } \\
\text { steppe } \\
\text { right bank } \\
\text { Polissya } \\
\text { Steppe }\end{array}$ & $1,4-1,9$ & $\begin{array}{l}2,4-2,6 \\
3,1-3,5 \\
3,0-3,3\end{array}$ & $19-20$ & $\begin{array}{l}25-26 \\
26-27\end{array}$ \\
\hline II & $\begin{array}{l}\text { RVR-2 Estimation of off- } \\
\text { spring of individual plants } \\
\text { in a complex of varietal } \\
\text { adaptive features and } \\
\text { removal of undesirable }\end{array}$ & $\begin{array}{l}\text { Forest- } \\
\text { step left } \\
\text { bank }\end{array}$ & $\begin{array}{l}\text { Forest- } \\
\text { step left } \\
\text { bank }\end{array}$ & $1,6-1,9$ & $3,5-3,7$ & $18-19$ & $27-28$ \\
\hline III & $\begin{array}{l}\text { Reproduction (individual } \\
\text { selections of RVR-1), } \\
\text { isolated according to a } \\
\text { set of features in RVR-2, } \\
\text { are combined and sown, } \\
\text { feed grade varieties are } \\
\text { obtained }\end{array}$ & $\begin{array}{l}\text { Forest- } \\
\text { step left } \\
\text { bank }\end{array}$ & $\begin{array}{l}\text { Forest- } \\
\text { step left } \\
\text { bank }\end{array}$ & $1,5-1,8$ & $3,4-3,9$ & $18-19$ & $27-28$ \\
\hline IV & $\begin{array}{l}\text { Reproduction (feed } \\
\text { seeds are sown and get } \\
\text { basic, they get } 25 \% \text { ) }\end{array}$ & $\begin{array}{l}\text { Forest- } \\
\text { step left } \\
\text { bank }\end{array}$ & $\begin{array}{l}\text { Forest- } \\
\text { step left } \\
\text { bank }\end{array}$ & $1,4-1,7$ & $3,3-3,8$ & $17-18$ & $26-28$ \\
\hline
\end{tabular}




\begin{tabular}{|l|l|l|l|l|l|l|l|}
\hline V & $\begin{array}{l}\text { Reproduction (Basic } \\
\text { seeding and seed re- } \\
\text { ceiving C (certified) }\end{array}$ & $\begin{array}{l}\text { Forest- } \\
\text { step left } \\
\text { bank }\end{array}$ & $\begin{array}{l}\text { Forest- } \\
\text { step left } \\
\text { bank }\end{array}$ & $1,4-1,6$ & $3,5-3,8$ & $17-18$ & $26-27$ \\
\hline VI & $\begin{array}{l}\text { Reproduction (seeding } \\
\text { of seed C and receiving } \\
\text { C) }\end{array}$ & $\begin{array}{l}\text { Forest- } \\
\text { step left } \\
\text { bank }\end{array}$ & $\begin{array}{l}\text { Forest- } \\
\text { step left } \\
\text { bank }\end{array}$ & $1,3-1,7$ & $3,4-3,7$ & $17-18$ & $27-28$ \\
\hline VII & $\begin{array}{l}\text { Reproduction (seeding of } \\
\text { C: seeds and getting C:) }\end{array}$ & $\begin{array}{l}\text { Forest- } \\
\text { step left } \\
\text { bank }\end{array}$ & $\begin{array}{l}\text { Forest- } \\
\text { step left } \\
\text { bank }\end{array}$ & - & - & - & - \\
\hline
\end{tabular}

The method of obtaining mutant beet lines on the basis of induced mutagenesis for the establishment of a positive effect in obtaining valuable micro-mutations in offspring (treatment of seed NEU at a dose of $1 \mathrm{mg} / \mathrm{l}$ at 18 hours before sowing) was developed.

Scientific and practical way to use this development: the method was tested in creating mutant strains Betaninchik, Elipse (K-1835), Desert (K-1836), Tsukerka (K-1837) (Figure 1, scheme 1).

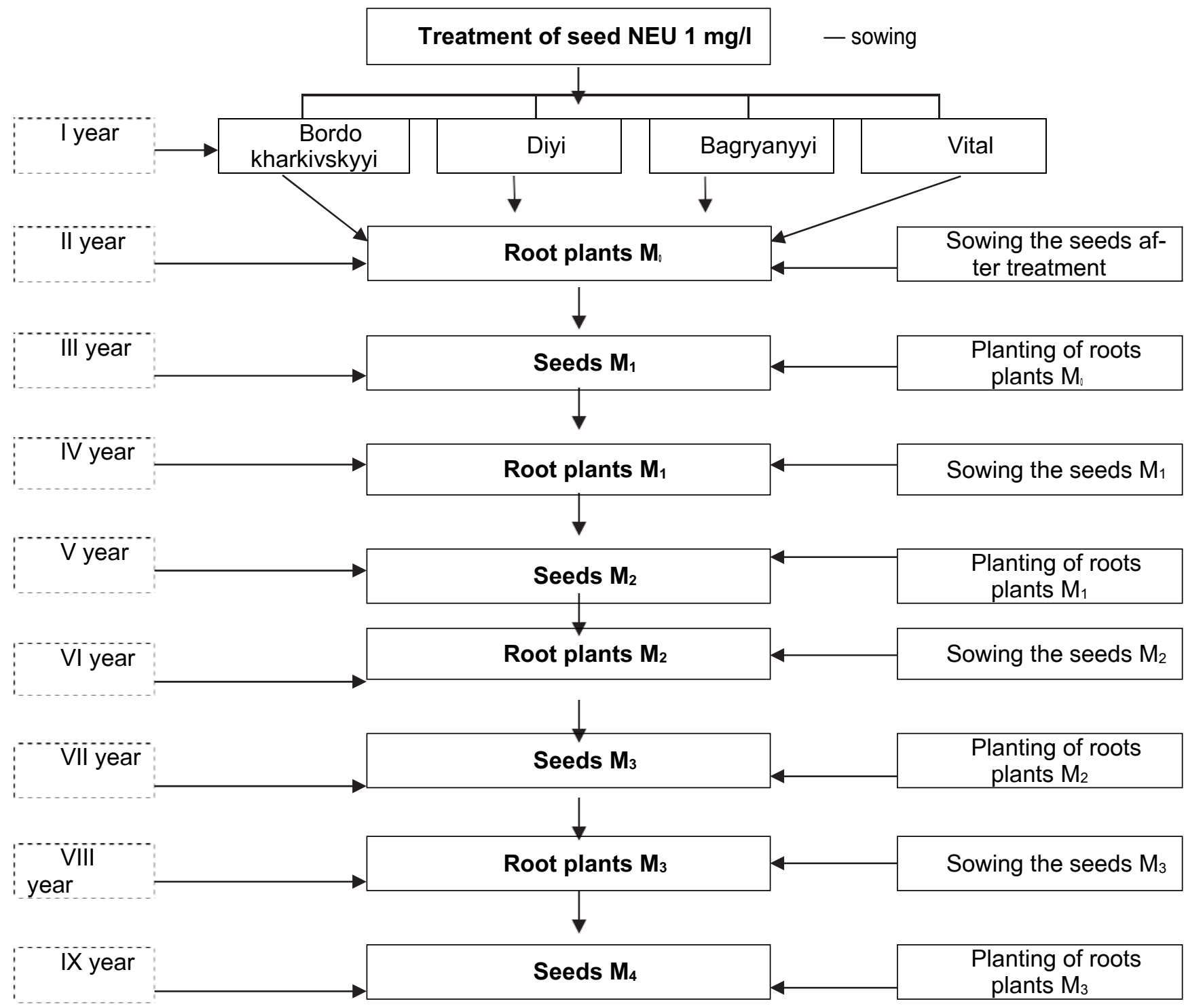

Fig. 1 Scheme of creating mutant of beet table lines 
The "Method for obtaining lines and hybrids of table beet on the basis of phytohormones" has already been develop for the determination of the mutagenic action of gibberellic acid GA because of plant treatment in the phase of 6-7 leaves at a dose of $3 \mathrm{mg} / \mathrm{l}$.

Scientific and practical output from the application of this design: The method was tests when creating a new line of the Ball (k-2007). From the hybridization with the line of the ITS 047541, a heterozygous F1 round hybrid was obtained. The selection of parent components was carried out for the Euclidean distance of the cluster analysis, samples of Diyi and lц were identified 047541 (Figure 2).

Tree Diagram for 35 Cases

Complete Linkage

Euclidean distances

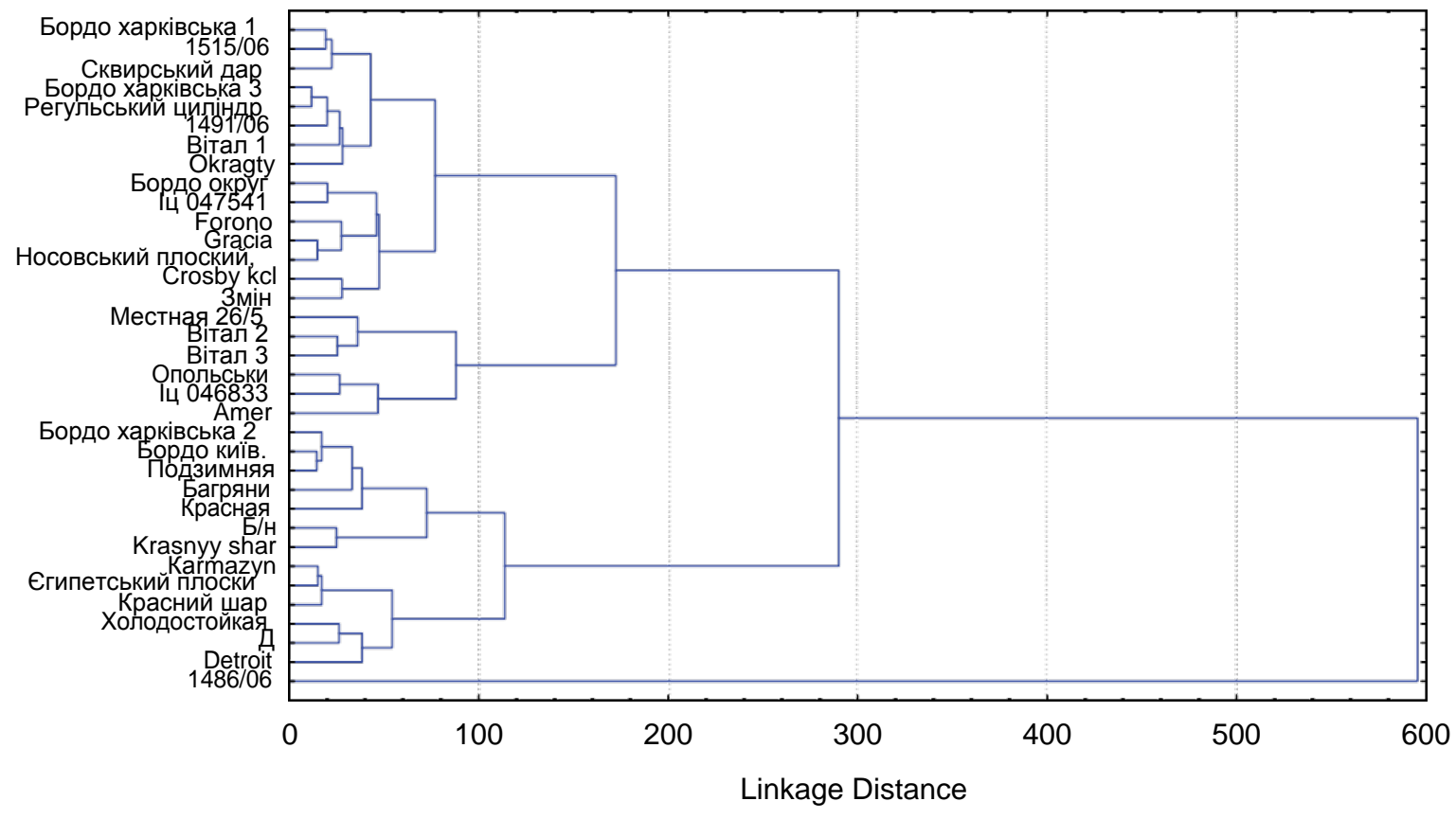

Fig. 2 Distribution of samples of beet dining for the Euclidean distance between morphological and productive features (average for 2013-2015).

For seed production, "A way to increase the yield of stallions and seeds of beet dining" (PCM №201603425) was develop because of the positive action of gibberellic acid.

The method of obtaining lines and heterozygous F1 beet table hybrids was create because of ecological heterosis from the interbreeding of self-closing lines in a hybrid (male sterility line of beet sugar monoetrophic / beet varieties of single and multi-seeded beets) with parental beet table varieties (Fig. 3).

The method was teste at the creation of multi-line lines 08-12 from Bordo kharkivskyyi (k-2008) - Bordova (k-3386) 08-104 from Bagryanyyi and (k-3383) 08-03 from Bordo kharkivskyyi. From hybridization with parent species, respectively, hybrids Merydian F1 (08-104 / Bagryanyyi) and Conus (08-03 / Bordo kharkivskyyi) were obtained from the introduction of which the economic effect was 50-75 thousand $\mathrm{UAH} / \mathrm{ha}$.

Because of hybridization, a one-seed line (k-3387) 08-73 from Delikatesnyyi with a Delikatesnyyi variety ware used to create a medium-term heterozyme hybrid Horyzont F1. It exceeded the yield standard by 2.8 times. The economic effect is 75.5 thousand $\mathrm{UAH} / \mathrm{ha}$. 


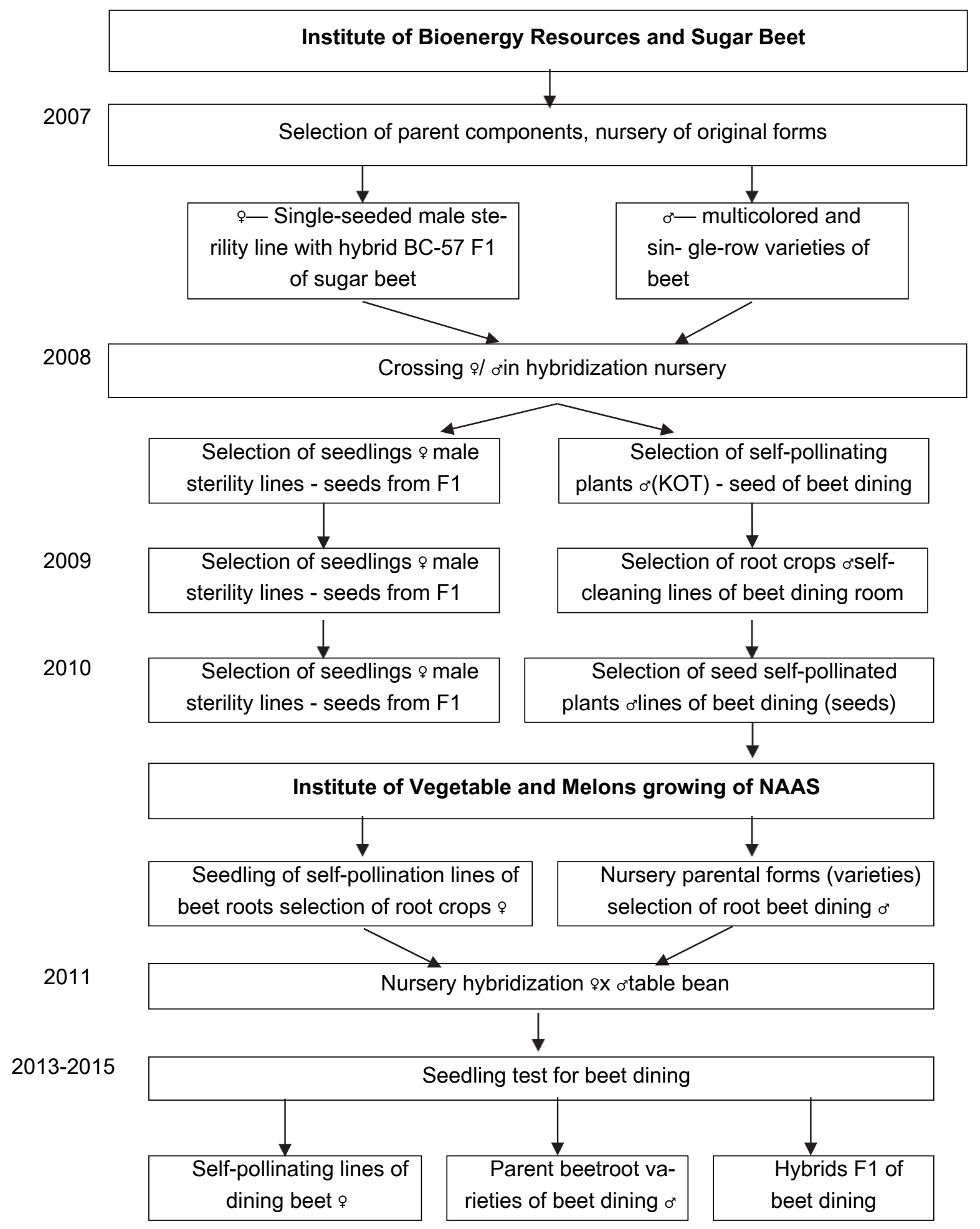

Fig. 3 Scheme for the creation of self-pollinating lines and hybrids F1 of beet dining

The method of creating new varieties of seedlings of salad is base on pre-seed treatment of seeds of the initial forms of $\gamma$-rays with a dose of $15 \mathrm{cr}$ (PCM №201507557). The scheme of selection process includes VI stages, during which individual selection of genotypes is carried out on economically valuable grounds, reproduction of the best genotypes with high productivity and qualitative indices, variety testing. At reproduction, unite not less than 100 families of the selected sample.

One of the developed methods involves the creation of homozygous for the necessary recessive tomato genome of hybrid populations F2 (Patent №25766UA). In this case, the parental forms have recessive genes in the genotype and a set of desirable features. 
The success of the creation of fertile and sterile lines of carrot varieties was facilitate by new methodical approaches developed by scientists:

- application in crossings of the initial sterile form of the petaloid type; selection of sterilization fixator, genetically close to male sterile form, fixation of sterility through 3-ocherovyh saturated crosses and selections (Patent № 37570 UA);

- use as a source material of male-sterile lines of foreign origin capable of forming fertile seeds without sterility for three periods of reproduction while retaining quantitative characteristics (Patent №44426 UA);

- creation of intsucht-lines by combining into groups of roots with similar characteristics (not less than 5 pcs.) (Patent № 79709 UA). Seeds from each group are obtain on isolated plots. Divers spend for 3 generations. In the fourth generation united more than 50 plants, carry out variety testing and reproduction. In this process, the inbreeding decreases to 3 generations, instead of 7-8.

Significant methodological developments in the IVM of NAAS were carry out by methods of propagation of seed materials:

- obtaining eggplant seeds by 2 times the one-off removal of the seedlings at the beginning of biological ripeness, leaving only 3 fruits on the plant (Patent №69575 u);

- obtaining quality uterus roots and high quality seeds of parsley curly for processing plants in the phase of 6-7 present leaves at intervals of 30 days with gibberellic acid GA in a dose of $3 \mathrm{mg} / \mathrm{l}$ alone or in a mixture with indolylacetic acid at a dose of $1 \mathrm{mg}$ / I (Patent №61941 UA);

- planting of beet plants for processing seed for $24 \mathrm{~h}$. The solution of the preparation Bayikal EM-1U at a dose of $1 \mathrm{ml} / \mathrm{l}$ (Patent №85787 UA);

- receipt of seed of early corn maize, plant placement scheme, introduction of organo-mineral fertilizers (Patent №069585 UA);

- a way of healing seed potato material for the use of chemical and biologically active substances ( $\mathrm{Pa}-$ tent №50407 UA);

- cultivation of common beans for the use of the microbial preparation Risobofit (strain I) (200 g per sowing unit) (Patent №97538 U).

Modern world selection of vegetable plants is aims at the signs of adaptability and product quality. In such directions, the scientists of the IVM of NAAS have developed a number of methods:

- an accelerated method for evaluating the characteristics of carrot samples in field conditions was developed on the basis of established correlations, which allowed to reduce the volumes of measurement to 4 characters, and in laboratories - for 5th (Table 3) (PCM №1000990 UA);

Such methods have created new lines of carrots Yasya, Mriya A, Mriya B, with increased performance and quality.

3. Direct correlations between quantitative biochemical, morphological, productive features and carrot yield (average 2010-2014)

\begin{tabular}{|l|l|c|l|l|l|l|}
\hline $\begin{array}{l}\text { № of var- } \\
\text { iants }\end{array}$ & $\begin{array}{l}\text { Investigated sign } \\
\text { (price of analysis, } \\
\text { UAH) }\end{array}$ & $\begin{array}{l}\text { № } \\
\text { analysis }\end{array}$ & \multicolumn{1}{|c|}{ Correlation sign } & $\begin{array}{l}\text { Price of } \\
\text { analysis, } \\
\text { UAH }\end{array}$ & $\begin{array}{l}\text { Correlation co- } \\
\text { efficients (r) }\end{array}$ \\
\hline \multicolumn{7}{|c|}{ Open ground 1st year of the plant Field analysis of root crops, yield } \\
\hline 1 & Outlet height (40.00) & 1 & Width of the socket & 40,00 & 0,66 \\
\hline 2 & $\begin{array}{l}\text { Larger root of root } \\
(40.00)\end{array}$ & 2 & $\begin{array}{l}\text { The smaller the diame- } \\
\text { ter of the root crop }\end{array}$ & 40,00 & 0,87 \\
\hline 3 & Root weight (40.00) & 3 & $\begin{array}{l}\text { Output of standard root } \\
\text { crops }\end{array}$ & 50,00 & 0,82 \\
\cline { 2 - 6 } & 4 & $\begin{array}{l}\text { Output of atypical root } \\
\text { crops }\end{array}$ & 50,00 & 0,75 \\
\hline 4 & $\begin{array}{l}\text { Output of standard } \\
\text { root crops (50.00) }\end{array}$ & 5 & Total yield & 50,00 & 0,70 \\
\cline { 2 - 6 } & & 7 & Root weight & 40,00 & 0,90 \\
\hline
\end{tabular}




\begin{tabular}{|l|l|c|l|l|l|}
\hline \multicolumn{9}{|c|}{ (I year) Laboratory, biochemical analysis of root crops } \\
\hline 5 & \multirow{2}{*}{ Dry substance (41.44) } & 8 & Protein $(\mathrm{N} \times 6.25)$ & 68,92 & 0,47 \\
\cline { 3 - 6 } & & 9 & Monosaccharides & 52,27 & 0,52 \\
\cline { 3 - 6 } & & 10 & Total sugar & 65,64 & 0,48 \\
\cline { 3 - 6 } & & 11 & Crop capacity & 50,00 & 0,58 \\
\hline 6 & & 12 & Folic acid & 62,44 & 0,45 \\
\cline { 3 - 6 } & & 13 & - carotene & 60,07 & 0,53 \\
\hline 7 & -carotene (60.07) & 14 & Length of the stalk & 40,00 & 0,46 \\
\hline 8 & total sugar (65,64) & 15 & Monosaccharides & 52,27 & 0,62 \\
\cline { 3 - 6 } & & 16 & Saccharose & 20,00 & 0,82 \\
\hline 9 & Monotsucrari (52,27) & 17 & Saccharose & 20,00 & 0,88 \\
\hline Total & 442.75 UAH. & \multicolumn{5}{|l}{} \\
\hline
\end{tabular}

- The method of growing carrot seeds by individual sampling of seed plants investigated by evaluating the seeds on the content of dry matter, fiber, sucrose, combining the best in one batch and producing reproductive and basic seeds (Table 4).

\section{Comparative characteristic of growing of high quality carrot seeds}

\begin{tabular}{|l|l|c|l|l|l|}
\hline № & $\begin{array}{l}\text { Nursey and opera- } \\
\text { tions }\end{array}$ & Year & Traditional method & Year & New method \\
\hline 1 & $\begin{array}{l}\text { Seed of seeds, } \\
\text { RVR-1 year }\end{array}$ & I & $\begin{array}{l}\text { Getting roots, selec- } \\
\text { tion }\end{array}$ & I & $\begin{array}{l}\text { Biochemical analysis of seeds 100 } \\
\text { pcs. Ind. rn (seedlings) and selec- } \\
\text { tion for increased content of dry } \\
\text { matter, fiber and sucrose. }\end{array}$ \\
\hline 2 & Root landing & II & $\begin{array}{l}\text { Selection of an .dr of } \\
100 \text { pcs for a set of } \\
\text { valuable signs and a } \\
\text { pick-up for low seed } \\
\text { output below average }\end{array}$ & II & $\begin{array}{l}\text { Sowing of seeds and obtaining } \\
\text { elite roots }\end{array}$ \\
\hline 3 & $\begin{array}{l}\text { Sowing of seeds, } \\
\text { RVR-II Year }\end{array}$ & III & $\begin{array}{l}\text { Estimation of root } \\
\text { crops and allocation } \\
\text { of typical productive } \\
\text { offspring }\end{array}$ & III & $\begin{array}{l}\text { Sowing of elite seeds, obtaining } \\
\text { basic root crops }\end{array}$ \\
\hline 4 & $\begin{array}{l}\text { Planting Roots Re- } \\
\text { production }\end{array}$ & IV & Getting of elite seeds & IV & Getting of basic seeds \\
\hline 5. & Sowing of seeds & V & Getting of elite roots & V & \\
\hline 6. & Root landing & VI & Getting of elite seeds & VI & - \\
\hline 7. & Sowing of seeds & VII & Getting of elite roots & VII & - \\
\hline 8. & Root landing & VIII & Getting of elite seeds & VIII & \\
\hline
\end{tabular}

The application of the method led to an increase in the yield and quality of seeds by $16-20 \%$ with a reduction in the terms of obtaining it for 4 years;

- determining the content of sugar in the bean seeds by conventional means of replacing hot alcohol extraction with cold water for 2 hours, which prevented the hydrolysis of starch and increased the accuracy of the determination (Table 5) (PCM №77187 UA); 
5. Comparative results of total sugar (\%) by different extraction methods in common bean (physiologically mature of seeds).

\begin{tabular}{|l|l|l|l|l|l|}
\hline Variety & $\begin{array}{l}\text { Hot alcohol ex- } \\
\text { traction }(\mathrm{St})\end{array}$ & $\begin{array}{l}\text { Cold water ex- } \\
\text { traction }\end{array}$ & $\begin{array}{l}\text { Error to } \\
\text { standard,\% }\end{array}$ & $\begin{array}{l}\text { Hot water ex- } \\
\text { traction }\end{array}$ & $\begin{array}{l}\text { Error to } \\
\text { standard,\% }\end{array}$ \\
\hline Shakhynya & 4,04 & 4,08 & 0,99 & 4,52 & 11,88 \\
\hline Gayidarska & 4,22 & 4,25 & 0,71 & 4,65 & 10,19 \\
\hline B/n 11 & 5,48 & 0,55 & 6,71 & 22,45 \\
\hline SSD & 0,04 & 5,51 & \multicolumn{5}{|l|}{} \\
\hline
\end{tabular}

- the method for determining crude fiber in vegetable and mélange products has been improved by increasing the extraction time by sulfuric acid and caustic potassium twice, increasing the concentration of sulfuric acid by 1,7 times, replacing diethyl ether with ethyl acetate ether (Table 6) (PCM №76376 UA);

6. Comparative results of determination of fiber in two methods

\begin{tabular}{|c|c|c|c|}
\hline Culture & $\begin{array}{c}\text { ISSN } \\
13496.2-91, \%\end{array}$ & Modified method, \% & Literary data, \% \\
\hline \multirow{3}{*}{ Carrot } & 1,82 & 1,04 & \multirow{3}{*}{$0,9-1,5(1,1)$} \\
\hline & 2,01 & 1,13 & \\
\hline & 1,92 & 1,08 & \\
\hline $\mathrm{SSD}_{\sharp}$ & & 0,03 & \\
\hline \multirow{3}{*}{ Sweet pepper } & 2,21 & 1,38 & \multirow{3}{*}{$1,1-2,1(1,36$} \\
\hline & 2,59 & 1,54 & \\
\hline & 2,23 & 1,18 & \\
\hline $\mathrm{SSD}_{k}$ & & 0,02 & \\
\hline \multirow{3}{*}{ Table beet } & 1,20 & 0,91 & \multirow{3}{*}{$0,7-1,2(0,9)$} \\
\hline & 1,50 & 1,11 & \\
\hline & 1,08 & 1,08 & \\
\hline $\mathrm{SSD}_{\sharp}$ & & 0,03 & \\
\hline \multirow{3}{*}{$\begin{array}{c}\text { Vegetable Beans } \\
\text { (grain) }\end{array}$} & 4,08 & 3,37 & \multirow{3}{*}{$2,5-4,7(3,5)$} \\
\hline & 3,78 & 2,59 & \\
\hline & 3,93 & 2,77 & \\
\hline $\mathrm{SSD}_{k}$ & & 0,16 & \\
\hline \multirow{3}{*}{ Water melon } & 0,84 & 0,62 & \multirow{3}{*}{$0,5-0,9$} \\
\hline & 0,76 & 0,58 & \\
\hline & 0,83 & 0,65 & \\
\hline $\mathrm{SSD}_{\sharp}$ & & 0,02 & \\
\hline
\end{tabular}

- Accelerated sampling method for determining $\beta$ - carotene in roots of carrots due to analysis of the lower part of the root crop and planting into the soil of its upper part (Patent № 24927 UA);

- a method of increasing $\beta$-carotene and ascorbic acid in tomato fruit was developed by sampling in a hybrid $F_{2}$ population of plants, homozygous for B-genes (orange fetus) and dg (increased immature fungal pigmentation). Allocate genotypes $\mathrm{B} / \mathrm{B} 1 / \mathrm{dg} / \mathrm{dg}$ and among them determine the content of $\beta$-carotene and ascorbic acid (Patent № 25767 UA);

- the method of determination of $\beta$-carotene in tomato fruits has been improved due to application for extraction of anhydrous sodium sulfate, which accelerates the assessment by 2-3 times (Patent № 30601 UA); 
- a method for the formation of lean tomato varieties with high content of $\beta$-carotene in fruits by selection of $F_{l}$ plants is homozygous for $B$ genes (orange fruits) and alc (delayed yields of fruits). $F_{2}$ genotype B/B1/alc/alc is extracted with further determination of $\beta$-carotene content (Patent № 32553UA);

- Modified laboratory method for determining the salt tolerance of bitter pepper in the application of seed germination in Petri dishes in saline solution (1.53\% NaCl) (Patent № 30269UA);

- a laboratory method was proposed for determining the cold resistance of bitter pepper by seed germination in Petri dishes at a temperature of $10^{\circ} \mathrm{C}$ for 15 days (Patent № $30268 \mathrm{UA}$ ).

An important step in the use of vegetable products is its processing. In the process of processing, it is necessary to maximally of preserve the presence of valuable substances in the processed product [4]. The scientists of IVM of NAAS have developed a number of methods for the products of its processing:

- by way of establishing correlation between the complex of signs of a tomato plant, the biochemical composition of the fruits and the index of the content of ascorbic acid in canned food, a method for predicting the content of ascorbic acid in canned food "Natural tomato juice" (Patent № 40683 UA) was proposed;

- due to the establishment of correlation dependencies developed a way to predict the content of dry matter in canned food "Natural tomato juice" (Patent № 55112 UA);

- for the study of methods of fermentation of eggplant fruits for the addition of a food preservative, suppressing the activity of undesirable micro flora, have created a method of fermentation of eggplant (Patent № 65370 UA);

- proposed a method for calculating the preservation of ascorbic acid in the production of "sweet peeled sweet marinated" by studying the signs of fetuses and preservation of ascorbic acid in canned food and creating an appropriate regression equation (Patent №74571 UA);

- study of morphological and biochemical parameters of cabbage of the white-and-tasting evaluation of fermented cabbage, has allowed to create a "Method of forecasting of organoleptic parameters of sauerkraut" (Patent № 74572 UA).

Due to the developed methods and methods of breeding by the Institute of Vegetable and Melons growing, the National Academy of Sciences of Ukraine created and entered in the State Register of plant varieties suitable for the distribution in Ukraine of 266 varieties and 31 hybrids of vegetable and melon crops, incl. for the last five years - 49 samples. The number of sorts and hybrids of the selection of IVM of NAAS makes up $45 \%$ of the total number of registered.

\section{Conclusions}

The methods and techniques of creation, estimations, selection of the source material, varieties, hybrids F1 of vegetable and melon crops, which were protect by patents, have already be proposed. The application of the developed methods allows optimizing the breeding process, accelerating the stabilization of the source material, expanding the genetic diversity of the populations, reducing the timing of the selection and seed processes, creating an intuitional linear sterile basis and increasing the productivity and quality of vegetable products, improving the economic performance, creating and reproducing of new samples.

\section{References}

1. Adaptivnaya selektsiya. Teoriya I takhnologiya na sovremennom etape / [P. P. Litun, V.V. Kirichenko, V.P. Petrenkova, V.P. Kolomatskaya]. — Kharkov, 2007 - 263s.

2. Waddington G.N. Evolutionary adaption /G. H. Waddington // In.: Evolution after Darvin. - Chicago: Univ. press., 1960. - V. 1. - H. 381-402.

3. Summerfield R.J, Ellis R.H., Craufuret P.Q. Phenological adaptation to cropping environment. From evaluation descriptors of times to flowering to photoperiod and temperature // PAP $14^{\text {th }}$ EUCARPIA Congr. Adapt. Plant. Breed. 1995. — 1996. — 92. - №1-2. - P. 281-286.

4. Suchasni metody selektsii ovochevykh i bashtannykh kultur / [za red. Go- rovoi T. K., Yakovanko K. I.]. - Kh., 2001. $-432 \mathrm{~s}$. 
5. Metodyka doslidnoi spravy v ovochivnytstvi I bashtannytstvi / [Bondarenko L.G., Yakovanko K. I.]; pid red. G.L. Bondarenka, K. I. Yakovenka. - Kh. : Osnova, 2001. - 369 s.

6. Nasinnytstvo I nasinneznavstvo ovochevykh I bashtannykh kultur / Za red. T. K. Gorovoi. - K. : Agrarna nauka, 2003. - $328 \mathrm{~s}$.

7. Suchasni tekhnologii v ovochivnytstvi / [za red K.I. Yakovenka]. - Kh. : IOB UAAN, 2001. - $128 \mathrm{~s}$.

8. Naukovo-praktychni pidkhody selektsii I nasinnytstva buryaka stolovogo. Teoriya I praktyka. / Za red. S. I. Kornienka.—Kh., 2013. - 136 s.

9. Netraditsionnye metody $v$ selektsii ovoshchnykh I bakhchevykh vidov rasteniyi / pod nauchn. red. V. A. Kravchenko, A. P. Samovola. - K. : Agrar. nauka, 2014. - 96 s.

10. Rappaport $L$. Effect of gibberellin on growth, flowering and fruiting of the Ear- lypak tomato, $L y c o-$ persicum esculentum / L. Rappaport // Plant Physiology, 1957. — Vol. 32, № 5. - P. 440 - 444.

11. Wittwer S. H. Some effects of gibberellin on flowering and fruit setting / S. H. Wittwer, M. J. Bukovac, H. M. Sell, L. E. Weller // Plant Physiology, 1957. — Vol. 32, № 1. P. - 39-41.

12. Morelock T.E. Influence of cytoplasmic source on expression of male sterility in carrot (Daucus carota L.) [Text] / T. E. Morelock // Dissertation Abstr. International. - 1974. - Vol. 35. - 114 p.

13. Dobzhansky Th. Nature and origin of heterosis [Text] / Th. Dobzhansky // Heterosis. - Ames. 1952. - P. $218-223$.

14. Sidark G. H. Effect of low doses of gamma irradiation on the growth and yield of two cultivars of tomato / G. H. Sidark, A. Suess // Radiat. Bot., 2003. - Vol. 3. - P. 54-63.

15. Perechen GOSTov na metodiki izmereniyi I analiza khimicheskogo sostava ovoshchnykh kultur I pochv. - Kharkov, 2002. - $5 \mathrm{~s}$. 